\title{
MEDICINAL HERBS USED IN MANAGEMENT OF MALARIA IN PAMOTAN VILLAGE COMMUNITY, KALIPUCANG DISTRICT, PANGANDARAN REGENCY, WEST JAVA, INDONESIA
}

\author{
AMI TJITRARESMI*, MOELYONO MOEKTIWARDOYO, YASMIWAR SUSILAWATI
}

Faculty of Pharmacy, Universitas Padjadjaran, Jl. Raya Bandung Sumedang Km 21, Jatinangor, Sumedang 45363

Email: ami.tjitraresmi@unpad.ac.id

Received: 05 Aug 2021, Revised and Accepted: 15 Oct 2021

\begin{abstract}
The aim of this study was to investigate medicinal plants used to treat malaria by a society in Pamotan village, Pangandaran Regency, West Java Province, Indonesia. The work was conducted using the Participatory Rural Appraisal (PRA) method, which is an assessment process-oriented to active community involvement in the form of direct interview activities. Information was collected by interviewing respondents using a semistructured questionnaire. Interviews were directed to the plants used to prevent and overcome malaria by referring to the list of questions which included the local name of the plant, the part used and the method of preparation and administration. A total of 47 respondents were interviewed of which $43 \%$ were females and $57 \%$ males. Results indicated that thirteen species of plants belonging were used to treat malaria by the villagers of Pamotan. The three plants that have the highest citation frequency are bitter herbs (Andrographis paniculata Ness.) 35.71\%, papaya leaves (Carica papaya L.) $21.43 \%$, and cut leaf ground cherry whole plants (Physalis angulata L.) $21.43 \%$. The most common preparation method is decoction and the route of administration is oral. It is concluded that the Pamotan villagers in Pangandaran district, Indonesia, still use ingredients from plants as complementary medicine to treat malaria.
\end{abstract}

Keywords: Ethnopharmacology, Pamotan village, Antimalarial herbs

(C) 2021 The Authors. Published by Innovare Academic Sciences Pvt Ltd. Thisis an open access articleunder theCC BYlicense (https://creativecommons.org/licenses/by/4.0/) DOI: https://dx.doi.org/10.22159/ijap.2021.v13s4.43816 Journal homepage: https://innovareacademics.in/journals/index.php/ijap

\section{INTRODUCTION}

Malaria is a tropical disease caused by the parasite Plasmodium $s p$., which can infect humans through the bite of female mosquitoes of Anopheles $s p$ [1]. The types of plasmodium that can cause malaria in humans are $P$. falciparum, $P$. vivax, $P$. ovale, $P$. malariae and $P$. knowlesi. P. falciparum is the most deadly Plasmodium type of malaria [2-4]. Globally, malaria is still a significant health problem because this disease affects a sizable population in the world. WHOreports that in 2017 there were around 219 million cases of malaria with a mortality rate of 435,000 [5].

The global commitment of leaders of the member states of the nations in the Millennium Development Goals (MDGs) began in September 2000, placing efforts to eradicate malaria in the seventh MDGs goals, which is to eradicate HIV/AIDS, malaria and tuberculosis. This commitment continued with SDGs (Sustainable Development Goals) with a validity period from January 2016 to December 2030. The objectives to be achieved by the SDGs include improvements in health and welfare, such as stopping HIV/AIDS, malaria, tuberculosis and other tropical diseases epidemics [6, 7].

The Ministry of Health of the Republic of Indonesia reported in the 2016 Indonesian Health Profile, the level of malaria endemicity in Indonesia in 2016, showed that only $48.1 \%$ of districts/cities were certified free of malaria [6]. The West Java Provincial Health Office in the West Java Provincial Health Profile in 2016, reported that the Malaria Morbidity or API (Annual Prevalence Incidence) for West Java in 2016 was $0.211 \%$. Regions in West Java that are still malaria-endemic areas are Sukabumi Regency, Garut Regency, Tasikmalaya Regency and Pangandaran Regency [8].

Pamotan Village, Kalipucang District, Pangandaran Regency is a village that has a history of being a high malaria-endemic area (until 2012, Pamotan Village, Kalipucang District is within the area of Ciamis Regency). Malaria cases in Pamotan began to increase in 1998 with 25 patients found, all positive for Plasmodium falciparum infection due to local transmission. Until 2005, the number of sufferers continued to increase and included strata of high case incidence or HCI [9]. The cause is a high population mobilization because Pangandran district is a tourist area with natural fishing attractions, bordering directly with the high malaria-endemic areas of the Cilacap Regency, Central Java Province, and the environmental conditions that allow for the life and development of Anopheles spp. Potential breeding sites for malaria vectors are river and lagoon estuaries, brackish water paddies, ponds, small ripples in the soil around the estuary and open waters in mangrove forests that continue to expand because the trees are turned into firewood in the process of processing coconut sugar [10].

Malarial drug resistance is the ability of parasites to continue to live in the human body, reproduce and cause symptoms of the disease even though it has been given regular treatment both with standard doses and with higher doses that can still be tolerated by drug users [11]. Plasmodium falciparum resistance to antimalarial drugs is a problem, especially in endemic areas [12]. This can increase morbidity and mortality due to malaria. Resistance occurs mainly because of mutations in Plasmodium genes, such as the mutation of 'Plasmodium falciparum Chloroquine Resistance Transporter' (PfCRT), Plasmodium falciparum dihydrofolate reductase (dhfr) and dihydropteroate synthase (dhps) genes [13]. The incidence of Plasmodium resistance to malarial drugs such as the quinolone group continues to increase and even now cases of Plasmodium falciparum resistance to artemisinin, which is a new generation of malarial drugs recommended by WHO, has been found and the widespread of resistance has encouraged researchers to seek for more effective antimalarial drugs [11].

The use of traditional medicines is an alternative for malarial treatment in endemic countries, such as Indonesia. This is because Indonesia is one of the largest countries rich in biodiversity and marine biota. In addition, the majority of Indonesian people still use plants as traditional medicines because they are believed to have medicinal properties [14].

Ethnopharmacology is the interdisciplinary science that investigates the perception and use of pharmaceuticals, especially traditional medicine, within ethnic society. Ethnic empirical knowledge is different in each region, depending on the distinctive nature and cultural wisdom of each ethnic group [15]. Based on the background above, it is necessary to conduct the ethnobotany survey for antimalarial of plants used by the Sundanese community in Pamotan village, Pangandaran Regency, West Java Province, Indonesia, in order to provide documentation of the plants used by the Pamotan villagers to treat malaria and this is the first step in the search for new malaria medicines from plants. 


\section{METHODS}

\section{Study area}

The ethnopharmacology survey was carried out in Pamotan village, Pangandaran Regency in West Java Province, Indonesia (fig. 1). Pangandaran Regency lies within the latitudes $7^{\circ} 41^{\prime} 3.66^{\prime \prime} \mathrm{S} 108^{\circ}$
39' 34.344" E. Pangandaran Regency is one of the endemic areas of malaria in West Java province of Indonesia, and Pamotan village located in the district of Kalipucang has the highest malaria incidence rates in Pangandaran Regency every year. Pamotan village has an area of 5,34 $\mathrm{km}^{2}$. There are about 4.097 people living in Pamotan village, or 918,91 people densities per square $\mathrm{km}$ [16].

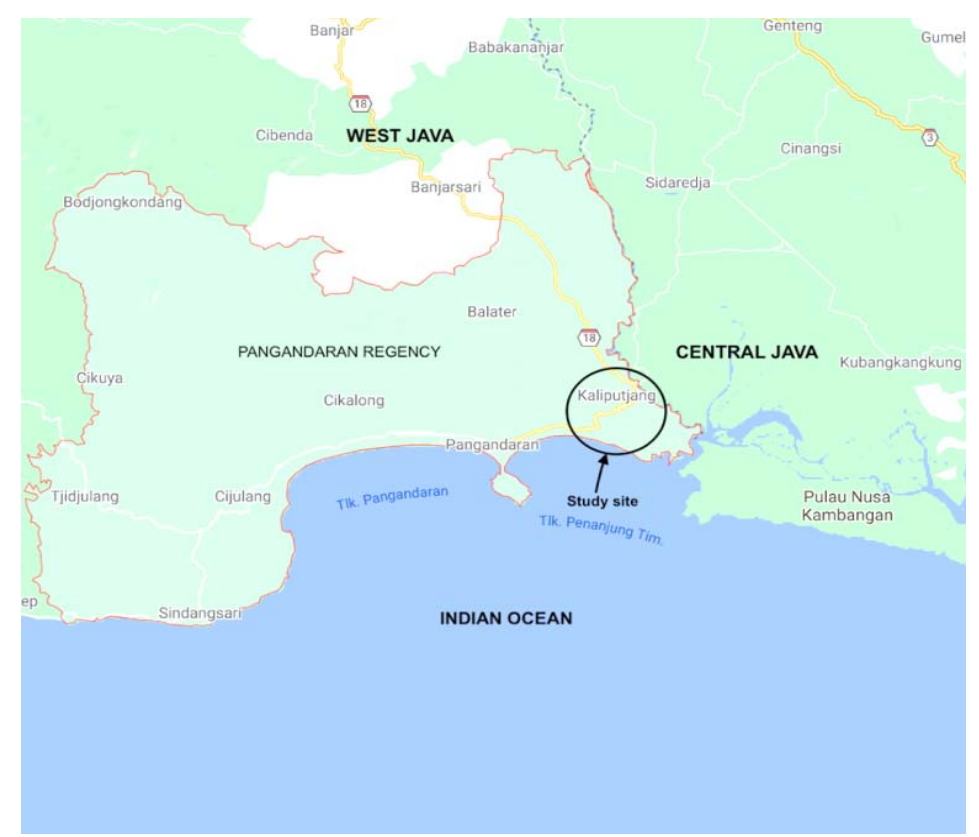

Fig. 1: Map of ethnopharmaceutical study area in Pangandaran Regency, Kalipucang District (https://www.google.com/maps/place/Pangandaran)

\section{Ethical approval for the study}

Ethical approval for the ethnopharmacology survey was obtained from the Health Research Ethics Commission Faculty of Medicine, Universitas Padjadjaran (1264/UN6. KEP/EC/2019). The participants in this research were provided with information such as the aim of the study, benefits and risk involved. Those who agreed to participate signed a written consent at the beginning of the study.

\section{Ethnopharmacology survey}

Ethnopharmacology research in malaria-endemic areas of West Java was carried out using the Participatory Rural Appraisal (PRA) method, which is an assessment process oriented towards active community involvement, in the form of direct interviews [17]. The survey was carried out from April to May 2019; semi-structured questionnaires were used to interview the local population about their knowledge of herbs used in the treatment of malaria. The selected respondents (inclusion criteria) are adult men or women from Pamotan village, Pangandaran district, who have knowledge about malaria and plants that are traditionally used to treat malaria. The preferred respondents are traditional healers, village leaders, village or sub-district malaria interpreters and people who know about malaria based on experience because they have suffered from malaria or have relatives who have suffered from malaria diagnosed by doctors at the local health center and have used or know plants to help treat malaria. The exclusion criteria were for children (under $18 \mathrm{y}$ of age), adults who did not know about malaria, its symptoms, and did not know about malaria treatment using plant materials and adults with dementia. The basic information needed was collected through conversations during the oral interviews. The data obtained is then analyzed both qualitatively and quantitatively, including the local name of the plant, the part of the plant used, and the method of use.

The random sampling technique was used in this study. Information such as the demographic structure of the community (age groups, sex of individuals, occupations, and education level) were generated and respondents gave information on parts of plants used in the treatment of malaria, mode of preparation, source of ethnopharmacological knowledge and source of material plant for medicine preparation $[17,18]$. The respondents accompanied the researcher to the field to take pictures and to collect plant materials. The plant samples used by the Pamotan village community based on the survey results were documented in the form of photographs and collected in the field to assist with identification. The collected plant materials were identified and deposited at Herbarium Bandungense Institut Teknologi Bandung. To find out the importance and level of confidence the use of these plants in dealing with malaria, the Frequency of citation (FC) was calculated [19].

The Frequency of citation (FC) for each medicinal plant is calculated using the formula:

$$
\mathrm{FC}=\frac{\text { the number of times the medicinal herbs were mentioned by respondents }}{\text { the total number of plant species used }} \times 100 \%
$$

\section{Phytochemical screening}

Phytochemical screening is carried out to determine the secondary metabolite group contained in a plant. The secondary plant metabolites tested included alkaloids, flavonoids, polyphenols, quinones, saponins, steroid-triterpenoids, and monoterpenoidssesquiterpenoids (essential oils). Phytochemical screening was tested on plant material using standard procedure [20,21].

\section{RESULTS}

Respondents of this study are residents of Pamotan village, adults (over 20 y old), know the diseases and symptoms of malaria, and know the plants used to treat malaria. Total number of respondents for this ethnopharmacology survey was 47 , and the majority of respondents were male (57\%). The distribution of the age, occupation and education level of the respondents is presented in fig. $2-4$. 


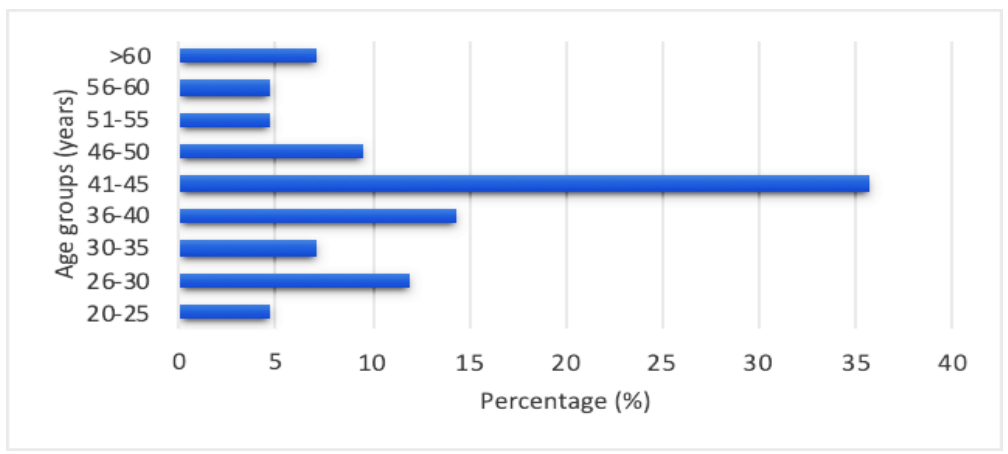

Fig. 2: Age groups of respondents

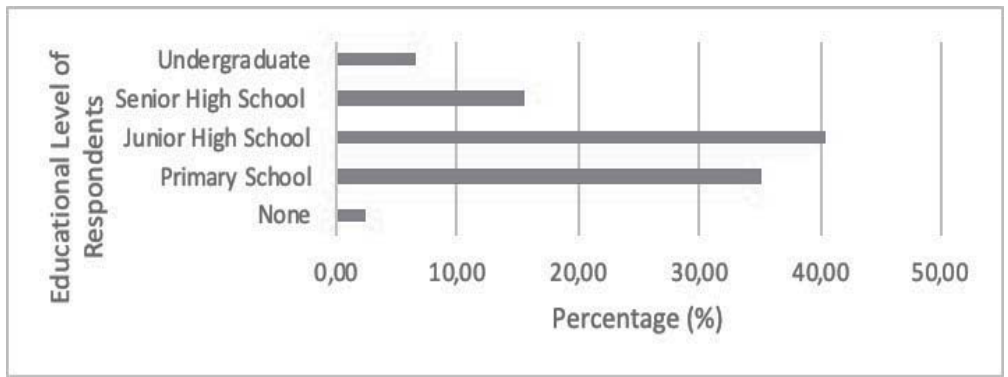

Fig. 3: Educational level of respondents

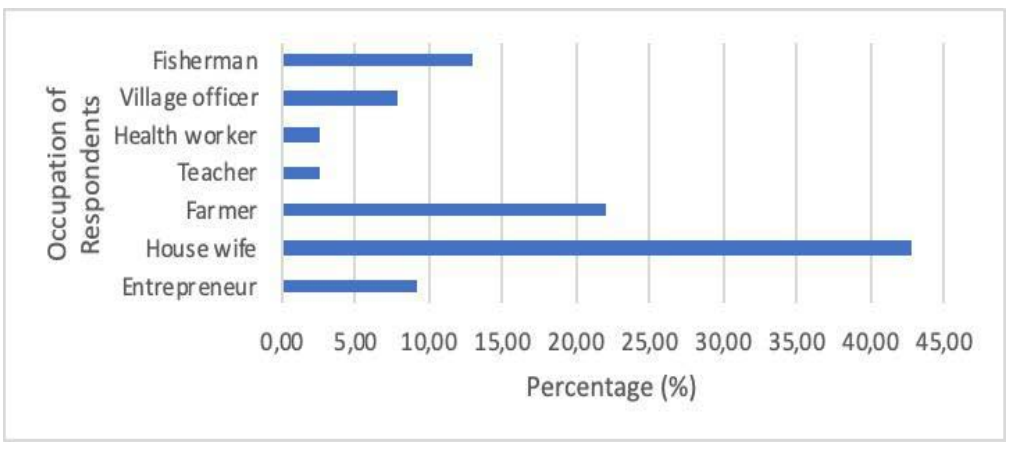

Fig. 4: Occupation of respondents

Community of Pamotan village utilizes medicinal plants majority based on traditional knowledge passed down from generation to generation
(69\%), and some people gain knowledge of medicinal plants by reading books and through electronic media or being told by friends (fig. 5).

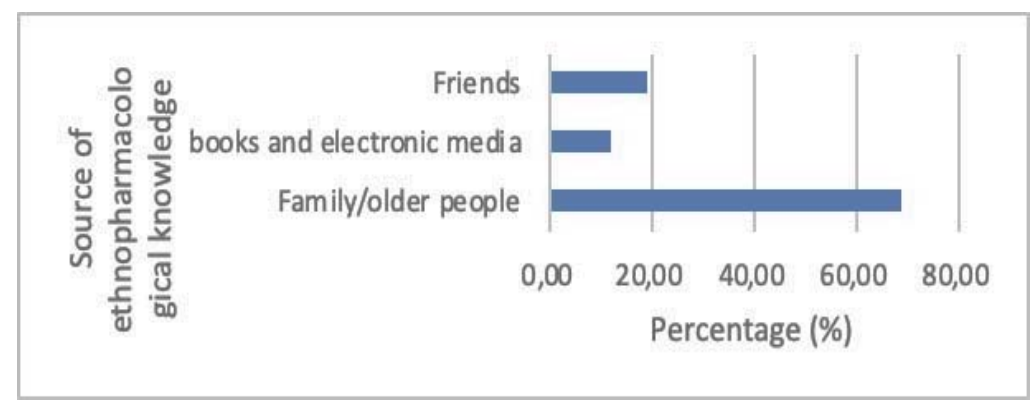

Fig. 5: Source of ethnopharmacological knowledge

The results of the ethnopharmaceutical survey in the form of scientific names, regional names, plant parts used and methods of making drugs used for malaria treatment by Pamotan villagers are presented in table 1 . The results of the ethnopharmacology survey in
Pamotan village, Pangandaran Regency showed a total of 13 plants species of plants belonging to 11 family used to treat malaria (fig. 6), and the distribution of plants part used to make a malaria medicine is shown at fig. 7. 
Table 1: Medicinal plants used to treat malaria in pamotan village community

\begin{tabular}{|c|c|c|c|c|c|c|}
\hline Voucher number & Family & Plant name & Local name & $\begin{array}{l}\text { Plant part } \\
\text { used }\end{array}$ & $\begin{array}{l}\text { Frequency of } \\
\text { citation (\%) }\end{array}$ & Mode of preparation \\
\hline $\begin{array}{l}\text { 4388/II. } \\
\text { C02.2/PL/2019 }\end{array}$ & Acanthaceae & $\begin{array}{l}\text { Andrographis } \\
\text { paniculata Ness. }\end{array}$ & Sambiloto, ki oray & Aerial part & 35,7 & Boil in water \\
\hline $\begin{array}{l}\text { 4835/II. } \\
\text { C02.2/PL/2019 }\end{array}$ & Asteraceae & Sonchus arvensis L. & $\begin{array}{l}\text { Tempuyung, } \\
\text { jombang }\end{array}$ & Leaves & 4,8 & Boil in water \\
\hline $\begin{array}{l}\text { 4835/II. } \\
\text { C02.2/PL/2019 }\end{array}$ & Asteraceae & Helianthus annuus L. & $\begin{array}{l}\text { Bunga Matahari, } \\
\text { srangenge }\end{array}$ & Leaves & 4,8 & Boil in water \\
\hline $\begin{array}{l}\text { 4835/II. } \\
\text { CO2.2/PL/2019 }\end{array}$ & Caricaceae & Carica papaya L. & Pepaya, gedang & Leaves & 21,4 & $\begin{array}{l}\text { Pound, add cold } \\
\text { water and squeezed }\end{array}$ \\
\hline $\begin{array}{l}\text { 4388/II. } \\
\text { C02.2/PL/2019 }\end{array}$ & Cucurbitaceae & Luffa acutangula L. & Oyong, emes & Seeds & 16,7 & $\begin{array}{l}\text { Dried and drink with } \\
\text { cold water }\end{array}$ \\
\hline $\begin{array}{l}\text { 4388/II. } \\
\text { CO2.2/PL/2019 }\end{array}$ & Cucurbitaceae & $\begin{array}{l}\text { Momordica charantia } \\
\text { L. }\end{array}$ & Pare, paria & Fruits & 2,4 & Boil in water \\
\hline $\begin{array}{l}\text { 4835/II. } \\
\text { CO2.2/PL/2019 }\end{array}$ & Meliaceae & $\begin{array}{l}\text { Swietenia } \\
\text { macrophylla King. }\end{array}$ & Mahoni & Seeds & 19,0 & $\begin{array}{l}\text { Dried and drink with } \\
\text { cold water }\end{array}$ \\
\hline $\begin{array}{l}\text { 4835/II. } \\
\text { C02.2/PL/2019 }\end{array}$ & Menispermaceae & Tinospora crispa L. & Bratawali & Stem & 16,7 & Boil in water \\
\hline $\begin{array}{l}\text { 4388/II. } \\
\text { C02.2/PL/2019 }\end{array}$ & Myrtaceae & Psidium guajava L. & $\begin{array}{l}\text { Jambu batu } \\
\text { beureum }\end{array}$ & Leaves & 11,9 & Boil in water \\
\hline $\begin{array}{l}\text { 4835/II. } \\
\text { C02.2/PL/2019 }\end{array}$ & Lamiaceae & $\begin{array}{l}\text { Plectranthus } \\
\text { Scutellarioides (L.) } \\
\text { Bth. }\end{array}$ & Miana, jawer kotok & Leaves & 9,5 & Boil in water \\
\hline $\begin{array}{l}\text { 4388/II. } \\
\text { C02.2/PL/2019 }\end{array}$ & Poaceae & Imperata cilyndrica $\mathrm{L}$. & Alang-alang & Roots & 2,4 & Boil in water \\
\hline $\begin{array}{l}\text { 4835/II. } \\
\text { C02.2/PL/2019 }\end{array}$ & Solanaceae & Physalis angulata L. & Cecendet & Whole plant & 21,4 & Boil in water \\
\hline $\begin{array}{l}\text { 4835/II. } \\
\text { CO2.2/PL/2019 }\end{array}$ & Zingiberaceae & $\begin{array}{l}\text { Kaempferia } \\
\text { galangal L. }\end{array}$ & Kencur & Rhizome & 2,4 & $\begin{array}{l}\text { Pound, add cold } \\
\text { water and squeezed }\end{array}$ \\
\hline
\end{tabular}

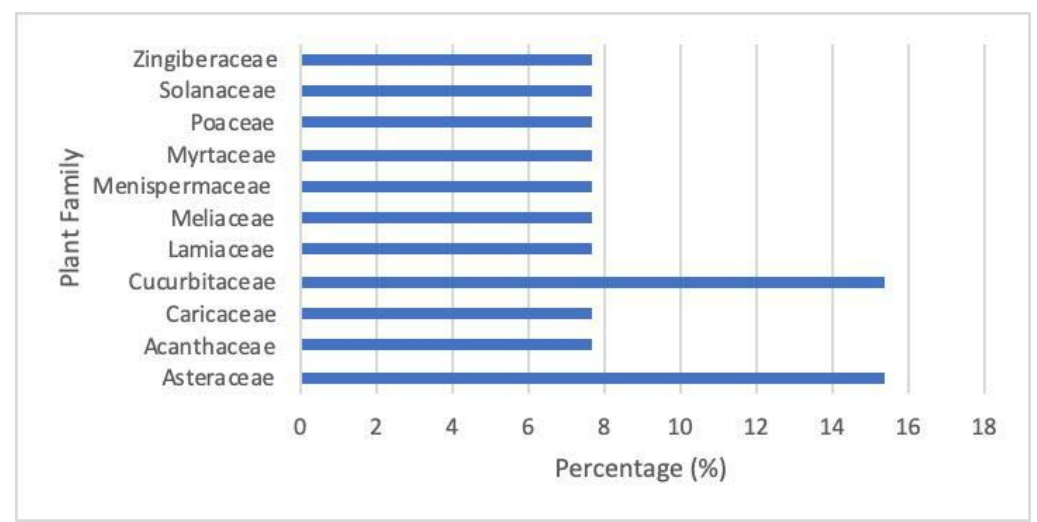

Fig. 6: Plant family used in the management of malaria in pamotan village community

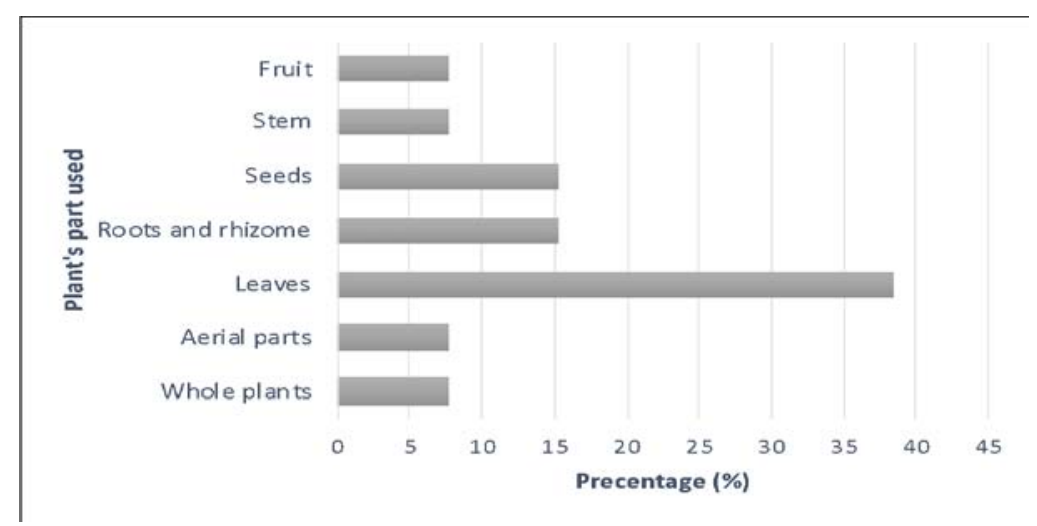

Fig. 7: Plants part used in the management of malaria in pamotan village community

Discovery of antimalarial activity publications in journals was conducted to see whether the plants used by the Pamotan village community had been examined for their antimalarial activity either in vitro or in vivo, as shown in table 2. 
Table 2: Literature review and phytochemical screening for the plants used for management of malaria among the Pamotan village community

\begin{tabular}{llll}
\hline Plant name & Plant part & In vitro and in vivo antimalarial activity & Phytochemical screening \\
\hline Andrographis & Aerial part & In vitro activity of heme polymerization inhibition: & Alkaloids, flavonoids, tannins, \\
paniculata Ness. & & (Extracts were obtained through multilevel extraction) & saponins, triterpenoids \\
& & IC $_{50} \mathrm{n}$-hexane extract $2196,57 \mu \mathrm{ml} / \mathrm{ml}$ & \\
& & $\mathrm{IC}_{50}$ ethyl acetate extract $1235,54 \mu \mathrm{g} / \mathrm{ml}$
\end{tabular}

C50 ethyl acetate extract $1235,54 \mu \mathrm{g} / \mathrm{ml}$

IC 50 ethanolic extract 70\% 1157,24 [22]

In vitro activity against 3D7 P. falciparum:

Sonchus arvensis $\quad$ IC 5 ethanolic extracts was $7.2 \mu \mathrm{g} / \mathrm{ml}$ [23].

No reference

Helianthus annuus L. Leaves In vitro activity against 3D7 P. falciparum:

$\mathrm{IC}_{50}$ of methanolic extract was $22.18 \mathrm{mg} / \mathrm{ml}$, and ethyl acetate fraction was $16.68 \mathrm{mg} / \mathrm{ml}[24]$.

Carica papaya L. Leaves $\quad$ Inhibition percentage against chloroquine-sensitive strain $P$.

falciparum of $150 \mu \mathrm{g} / \mathrm{ml}$ extract was $40,75 \%$.

Inhibition percentage against chloroquine resistance strain $P$.

falciparum of $150 \mu \mathrm{g} / \mathrm{ml}$ extract was 50,23\% [25].

In vitro activity against 3D7 P. falciparum:

$\mathrm{IC}_{50}$ of the aqueous extract was $166.0 \pm 1.23 \mu \mathrm{g} / \mathrm{ml} \mathrm{[26].}$

In vivo activity against $P$. berghei in mice:

Methanolic extract of papaya leaves at $400 \mathrm{mg} / \mathrm{kg} \mathrm{BW}$ and 200

$\mathrm{mg} / \mathrm{kg}$ BW showed a dose-dependent and progressive reduction in parasitaemia with time [27].

In vitro activity of heme polymerization inhibition:

$\begin{array}{ll}\text { Luffa acutangula (L.) } & \text { Seeds } \\ \text { Roxb. } & \\ \begin{array}{l}\text { Momordica } \\ \text { charantia } \text { L. }\end{array} & \text { Fruits }\end{array}$

$\mathrm{IC}_{50}$ of papaya leaves ethanolic extract was $7.914 \mathrm{mg} / \mathrm{ml}$ [28].

No reference

In vivo activity against $P$. berghei in mice:

The values of Inhibition percentages were $60.39 ; 86.46$ and $100 \%$ at

50,100 and $200 \mathrm{mg} / \mathrm{kg}$ BW respectively [29].

Alkaloid rich fraction:

$\mathrm{IC}_{50}$ value of the in vitro test against $P$. falciparum $3 \mathrm{D} 7$ was 0.17

$\mu \mathrm{g} / \mathrm{ml}$.

In vivo activity against $P$. berghei in mice using a suppressive and prophylactic method at a dosage of $100 \mathrm{mg} / \mathrm{kg} /$ day was found to inhibit parasites by 74 and $73 \%$, respectively [30].

\section{Swietenia}

macrophylla King.

Tinospora crispa $\mathrm{L}$.

Seeds

Stems

No reference

In vivo activity against $P$. berghei ANKA in mice

Crude extract at doses of 100 and $200 \mathrm{mg} / \mathrm{kg} \mathrm{BW}$ gave percent

inhibition of $35 \%$ and $50 \%$, respectively [31].

Psidium guajava L. Leaves $\quad$ In vivo activity against $P$. berghei in mice:

Ethanolic extract at $350 \mathrm{mg} / \mathrm{kg} \mathrm{BW}, 750 \mathrm{mg} / \mathrm{kg} \mathrm{BB}$ dan $1000 \mathrm{mg} / \mathrm{kg}$ BW gave Inhibition percentage (\%) of $80.2 \%$; $85.8 \%$ respectively [32].

In vitro activity $\mathrm{IC}_{50}$ on $P$. falciparum: $8 \mathrm{mg} / \mathrm{ml}$ [33].

In vitro activity of heme polymerization inhibition:

$\mathrm{IC}_{50}$ of guava leaves ethanolic extract was $8.794 \mathrm{mg} / \mathrm{ml}$ [28].

Plectranthus

Leaves

No reference

scutellarioides (L.)

Bth.

Imperata cylindrica

L.

Physalis angulata L.

Roots

No reference

Whole

plants

In vitro activity against 3D7 P. falciparum:

IC 50 of methanolic extract was $1.27 \mathrm{mg} / \mathrm{ml}$ (3D7), $3.02 \mathrm{mg} / \mathrm{ml}$ (W2),

$15.68 \mathrm{mg} / \mathrm{ml}$ (WI-38)[34].

In vivo activity against $P$. berghei in mice on day 9:

Ethanolic extract and aqueous extract at $300 \mathrm{mg} / \mathrm{kb} \mathrm{BW}$, gave

inhibition percentage of $61.2 \%$ and $61.8 \%$ respectively [34].

In vitro activity against 3D7 P. falciparum of antimalarial compound

isolated from Physalis angulata $\mathrm{L}$.:

Physalin B IC $502.8 \mu \mathrm{g} / \mathrm{ml}$

Physalin D IC $5055 \mu \mathrm{g} / \mathrm{ml}$

Physalin F IC $502.2 \mu \mathrm{g} / \mathrm{ml}$

Physalin G IC50 $6.7 \mu \mathrm{g} / \mathrm{ml}[35]$

Kaempferia

galanga L.
Rhizome No reference
Alkaloids, polyphenols, flavonoids, tannin, quinones

Alkaloids, polyphenols,

monoterpenoids-sesquiterpenoids

Alkaloids, flavonoids, polyphenols, saponins, triterpenoids

Flavonoids, tannins, quinones, saponins, steroids-triterpenoids Alkaloids, Flavonoids, saponins, steroids-triterpenoids

Alkaloids, tannins, saponins, steroids-triterpenoids Alkaloids, flavonoids, polyphenols, tannins, saponins

Alkaloids, polyphenols, flavonoids, tannin, quinones, saponins

Flavonoids, polyphenols, quinones, triterpenoids, monoterpenoidssesquiterpenoids Alkaloids, flavonoids, polyphenols, steroids-steroids

Alkaloids, polyphenols, flavonoids, tannin, saponins

Flavonoids, polyphenols, saponins, monoterpenoids-sesquiterpenoids

\section{DISCUSSION}

In this study, respondents were 47 respondents consisted of $43 \%$ females and $57 \%$ males in the age range $21-82 \mathrm{y}$, and most $(51 \%)$ were aged over $41 \mathrm{y}$ (fig. 2). This can be understood because older people are usually more experienced in using plant materials as medicine and have a better knowledge of herbal medicines. The educational level of respondents mostly was a primary school (35\%) and junior high school (40\%) (fig. 3). 
Occupations of the respondents included housewives, entrepreneurs, farmers, teachers, health workers, village employees and fishermen, and the types of occupations of the respondents were mostly housewives (42.9\%) (fig. 4). Housewives in Pamotan village are often involved in organizational activities in the village environment, one of which is making a garden that is planted with a variety of plants that are commonly used to treat common diseases in the community, so that the women in Pamotan village recognize and can use plants as medicinal ingredients, including for the treatment of malaria.

Majority of respondents in this study identified fever as the main symptom that is associated with malaria, the other symptoms mentioned included joint pains, nausea, headache, shivering body and diarrhea. Some respondents had experienced malaria or had family members who had had malaria so they know the symptoms of malaria properly.

Knowledge about the use of plants as malaria drugs in Pamotan village community is mostly known by passing down from generation to generation, and now with the development of information technology, this knowledge can be obtained from the internet. Medicinal plants are used as the first alternative step to treat diseases or as a supplement. The cultivated or wild plants are taken directly from the forest or home yard. Majority of the sources of medicinal ingredients are taken from wild plants around the village $(52,4 \%)$, some are taken from plants which are deliberately planted in the yard $(35,7 \%)$ and only a small proportion of them buy medicinal plants $(11,9 \%)$.

The The three plants that have the biggest frequency of citation are bitter herbs (Andrographis paniculata Ness.) 35.71\%, papaya leaves (Carica papaya L.) $21.43 \%$, and cutleaf ground cherry whole plants (Physalis angulata L.) 21.43\%, as shown in table 1.

There are various methods to prepare antimalarial medicines from plants among the community. The most common preparation identified in this study was boiling plant material (68\%) and other methods to prepare antimalarial medicine included dried, pounded and squeezed plant materials. Mostly the plant materials were harvested shortly before use.

Plant parts used by Pamotan village community (as a percentage of total plant parts used) are leaf (38\%), stem (8\%), fruit (8\%), seed $(15 \%)$, aerial parts $(8 \% \%)$, whole plant $(8 \%)$, root and rhizome $(16 \%)$. The leaf was the most commonly plant part used in management of malaria in this study, as shown in fig. 7.

Several plants, as shown on the table 2, have been tested for antimalarial and potential to be developed into malaria drugs, included aerial part of Andrographis paniculata Ness, Helianthus annuus L. leaves, Carica papaya L. leaves, Momordica charantia L. fruit, Tinospora crispa L. stem, and Psidium guajava L. leaves. Some plants such as tempuyung leaves (Sonchus arvensis L.), angled luffa seeds Luffa acutangula L., mahogany seeds (Swietenia macrophylla King.), miana leaves (Plectranthus Scutellarioides (L.) Bth.), alangalang roots (Imperata cylindrica L.), galangal rhizomes (Kaempferia galanga L.) have not been tested for their antimalarial activity, but miana leaves (Plectranthus Scutellarioides (L.) Bth) and mahogany seeds (Swietenia macrophylla King.) are traditionally used to treat malaria or used as an antipyretic [36, 37].

Quinine, the first malaria drug, is an alkaloid compound isolated from the Cinchona $s p$. and artemisinin is the malaria drug currently recommended by WHO which is a lactone sesquiterpene originally isolated from the Artemisia annua L. plant[38.39.40]. Based on phytochemical screening result, almost all plant material tested contained alkaloids except angled luffa seeds (Luffa acutangula L.), miana leaves (Plectranthus scutellarioides (L.) Bth.) leaves, and Kaempferia galanga L. rhizomes, while the plants containing monoterpenoid compounds and sesquterpenoid were sunflower leaves (Helianthus annuus L.), miana leaves (Plectranthus scutellarioides (L.) Bth.), and Kaempferia galanga L. rhizomes.

\section{CONCLUSION}

This study was provide the documentation of plants used in management of malaria among the Pamotan village community,
Pangandaran district, Indonesia. People still use plants as medicine because they are easy to get and affordable. The most widely used plant to treat malaria among the community in Pamotan village are bitter herbs (Andrographis paniculata Ness.), papaya leaves (Carica papaya L.), and cutleaf ground cherry whole plants (Physalis angulata L.). Some plants on the list have been tested for their antimalarial activity, however, some other plants have not been tested for their antimalarial activity either in vitro or in vivo, so it is necessary to examine the antimalarial activity of these plants. The results contributed to the conservation of empirical knowledge of medicinal plants used for the treatment of malaria, but its scientific validation claims of anti-malarial properties is imperative.

\section{ACKNOWLEDGEMENT}

The authors are indebted to the Directorate of Research, Community Service and Innovation, Universitas Padjadjaran, for the financial support through Academic Leadership Grant 2019, and to the respondents from Pamotan village community, who participated to share their valuable knowledge related to this study.

\section{FUNDING}

Nil

\section{AUTHORS CONTRIBUTIONS}

All the authors have contributed equally.

\section{CONFLICT OF INTERESTS}

Declared none

\section{REFERENCES}

1. Kajfasz P. Malaria prevention. Int Marit Health. 2009;60(12):67-70. PMID 20205131.

2. Mueller I, Zimmerman PA, Reeder JC. Plasmodium malariae and Plasmodium ovale- the "bashful" malaria parasites. Trends Parasitol. 2007;23(6):278-83. doi: 10.1016/j.pt.2007.04.009, PMID 17459775.

3. Collins WE. Plasmodium knowlesi: a malaria parasite of monkeys and humans. Annu Rev Entomol. 2012;57:107-21. doi: 10.1146/annurev-ento-121510-133540, PMID 22149265.

4. Beare NA, Taylor TE, Harding SP, Lewallen S, Molyneux ME. Malarial retinopathy: a newly established diagnostic sign in severe malaria. Am J Trop Med Hyg. 2006;75(5):790-7. doi: 10.4269/ajtmh.2006.75.790, PMID 17123967.

5. World Health Organization. Malaria; 2021. Available from: https://www.who.int/news-room/fact-sheets/detail/malaria. [Last accessed on 15 Jun 2021]

6. Kementerian kesehatan republik indonesia. Profil kesehatan Indonesia tahun 2016. Jakarta: Kementerian Kesehatan RI; 2017.

7. World Health Organization. Health in 2015: from MDGs, Millennium Development Goals to SDGs, sustainable $\begin{array}{lll}\text { development } & \text { goals. } & \text { Available }\end{array}$ https://apps.who.int/iris/handle/10665/200009 [Last accessed on 18 Jun 2020]

8. Jawa Barat DKP, Jawa Barat Tahun PKP, Jawa Barat DKP; 2016.

9. Hakim L, Sugianto. Prevalensi malaria asymptomatic pada kelompok penduduk paling Berisiko Tertular di kecamatan Kalipucang kabupaten Ciamis jawa barat. Aspirator. 2009;1(1):04-10.

10. Hakim L. Tempat perindukan nyamuk Anopheles spp. Di kecamatan Kalipucang Kab. Ciamis. Bulletin Penyakit Tular Vektor (Vector Borne Disease). Loka Litbang P2B2 Ciamis. 2004;1(2):32-9.

11. Talisuna AO, Bloland P, D'Alessandro U. History, dynamics, and public health importance of malaria parasite resistance. Clin Microbiol Rev. 2004;17(1):235-54. doi: 10.1128/CMR.17.1.235254.2004, PMID 14726463.

12. Olliaro PL, Bloland PB. Clinical and public health implications of antimalarial drug resistance. In: Rosenthal PJ, editor. Antimalarial chemotherapy: mechanisms of action, resistance, and new directions in drug discovery. Totowa, NJ: Humana Press; 2001.

13. Wellems TE, Plowe CV. Chloroquine-resistant malaria. J Infect Dis. 2001;184(6):770-6. doi: 10.1086/322858, PMID 11517439. 
14. Widoyono. Penyakit Tropis: Epidemologi, Penularan, Pencegahan and Pemberantasannya. 2nd ed. Jakarta: Erlangga; 2011.

15. Etnofarmasi MM, ed. Vol. 1. Yogyakarta: Deepublish; 2012.

16. Hakim L, Malaria di Desa Pamotan FRP, Pangandaran K. ASPIRATOR-Jurnal penelitian penyakit tular Vektor. J Vector Borne Diseases Studies 2013;5(2):45-54.

17. Martin GJ. Ethnobotany: A methods manual. London: Chapman and Hall; 1995.

18. Cunningham BA. Applied ethnobotany people, wild plant use, and conservation. London: Earthscan Publications Ltd.; 2001.

19. Hoffman B, Gallaher T. Importance indices in ethnobotany. Ethnobot Res Appl. 2007;5:201-18. doi: 10.17348/era.5.0.201218.

20. Farnsworth NR. Biological and phytochemical screening of plants. J Pharm Sci. 1966;55(3):225-76. doi: 10.1002/jps.2600550302, PMID 5335471.

21. Harborne JB. A guide to modern techniques of plant analysis. Phytochemical methods. 3rd ed. London, New York: Chapman and Hall; 1998.

22. Septiana E, Partomuan S. Toksisitas dan aktivitas antimalari penghambatan polimerisasi hem secara in vitro ekstrak daun sambiloto (Andrographis paniculata). Media Litbangkes. 2017;27(4):255-62.

23. Mishra K, Dash AP, Dey N. Andrographolide: A novel antimalarial diterpene lactone compound from Andrographis paniculata and its interaction with curcumin and artesunate. J Trop Med. 2011;2011:579518. doi: 10.1155/2011/579518.

24. Mutiah R, Badiah R, Hayati EK, Widyawaruyanti A. Activity of antimalarial compounds from ethyl acetate fraction of sunflower leaves (Helianthus annuus L.) against plasmodium falciparum parasites 3D7 Strain. Asian J Pharm Technol. 2017;7(2):61-5. doi: 10.5958/2231-5713.2017.00015.0.

25. Kovendan K, Murugan K, Panneerselvam C, Aarthi N, Kumar PM, Subramaniam J, Amerasan D, Kalimuthu K, Vincent S. Antimalarial activity of carica papaya (Family: Caricaceae) leaf extract against plasmodium falciparum. Asian Pac J Trop Dis. 2012;2(1):S306-11. doi: 10.1016/S2222-1808(12)60171-6.

26. Sannella AR, Karioti A, Orsini S, Scalone A, Gradoni L, Messori L, Severini C, Bilia AR. Leaf decoction of carica papaya combined with artesunate prevents recrudescence in Plasmodium berghei-infected mice. Planta Med. 2019;85(11-12):934-40. doi: 10.1055/a-0952-3677, PMID 31216580.

27. Longdet IY, Adoga EA. Effect of methanolic leaf extract of Carica papaya on Plasmodium berghei infection in albino mice. Eur J Med Plants. 2017;20(1):1-7. doi: 10.9734/EJMP/2017/34698.

28. Arifuddin M, Bone M, Rusli R, Kuncoro H, Ahmad I, Rijai L. Aktivitas Antimalaria penghambatan polimerisasi heme ekstrak etanol daun jambu biji (Psidium guajava) dan daun pepaya (Carica papaya). J Ilmiah Ibnu Sina. 2019;4(1):235-43. doi: $10.36387 /$ jiis.v4i1.246.
29. Akanji OC, Cyril Olutayo CM, Elufioye OT, Ogunsusi OO. The antimalaria effect of Momordica charantia L. and Mirabilis jalapa leaf extracts using animal model. J Med Plants Res. 2016;10(24):344-50. doi: 10.5897/JMPR2016.6046.

30. Abdillah S, Farida Y, Kartiningsih SNMD, Mohamad K. Antimalarial activity and toxicity evaluation of the alkaloid-rich fraction of Momordica charantia fruits. Int J Pharm Sci Res. 2019;10(5):2516-22.

31. Niljan J, Jaihan U, Srichairatanakool S, Uthaipibull C, Somsak V. Antimalarial activity of stem extract of Tinospora crispa against plasmodium berghei infection in mice. J Health Res. 2014;28(3):199-204.

32. Rajendran C, Begam M, Kumar D, Baruah I, Gogoi HK, Srivastava $\mathrm{RB}$, Veer V. Antiplasmodial activity of certain medicinal plants against chloroquine resistant Plasmodium berghei infected white albino BALB/c mice. J Parasit Dis. 2014;38(2):148-52. doi: 10.1007/s12639-013-0252-2, PMID 24808642.

33. Chinchilla M, Valerio I, Sanchez R, Mora V, Bagnarello V, Martinez L, Gonzalez A, Vanegas JC, Apestegui A. In vitro antimalarial activity of extracts of some plants from a biological reserve in Costa Rica. Rev Biol Trop. 2012;60(2):881-91. doi: 10.15517/rbt.v60i2.4024, PMID 23894953.

34. Lusakibanza M, Mesia G, Tona G, Karemere S, Lukuka A, Tits M, Angenot L, Frederich M. In vitro and in vivo antimalarial and cytotoxic activity of five plants used in congolese traditional medicine. J Ethnopharmacol. 2010;129(3):398-402. doi: 10.1016/j.jep.2010.04.007, PMID 20430094.

35. Sa MS, de Menezes MN, Krettli AU, Ribeiro IM, Tomassini TC, Ribeiro dos Santos R, et al. Antimalarial activity of physalins B, D, F, and G. J Nat Prod. 2011;74(10):2269-72. doi: 10.1021/np200260f, PMID 21954931.

36. Lisdawati V, Mutiartikum D, Alegantina S, Astuti Y, Miana KD. (Plectranthus scutellarioides (L.) Bth.) dan Buah Sirih (Piper betle L.) secara fisiko kimia dari ramuan lokal antimalaria daerah sulawesi utara. Media Litbang Kesehatan. 2008;18(4):213-25.

37. Kadota S, Marpaung L, Kikuchi T, Ekimoto H. Constituents of the seeds of Swietenia mahagoni Jacq. I. Isolation, structures, and $1 \mathrm{H}^{-}$and 13C-nuclear magnetic resonance signal assignments of new tetranortriterpenoids related to swietenine and swietenolide. Chem Pharm Bull. 1990;38(3):639-51. doi: 10.1248/cpb.38.639.

38. Tu Y. The discovery of artemisinin (qinghaosu) and gifts from Chinese medicine. Nat Med. 2011;17(10):1217-20. doi: 10.1038/nm.2471, PMID 21989013.

39. Klayman D. Qinghaosu (artemisinin): an antimalarial drug from. Chin Sci. 1998;228:1049.

40. Faurant C. From bark to weed: the history of artemisinin Parasite. 2011;18(3):215-8. doi: 10.1051/parasite/2011183215, PMID 21894261. 